\title{
Mites (Acari: Laelapidae) Associated with Sigmodontinae Rodents in Entre Ríos Province, Argentina
}

\author{
Agustín M Abba/ ${ }^{+}$, Daniel E Udrizar Sauthier*, José B Bender*, \\ Marcela Lareschi
}

\begin{abstract}
Centro de Estudios Parasitológicos y de Vectores, Calle 2 N$^{\circ}$ 584, 1900 La Plata, Argentina *Facultad de Ciencias Naturales y Museo, UNLP, La Plata, Argentina

The richness, diversity, abundance and prevalence of mite species associated with sigmodontine rodents of different species in Entre Rios province, Argentina are studied. Five of the six species of mites were reported for the first time in the study area. The richness and diversity of mites was higher on Oligoryzomys flavescens and $\mathrm{O}$. delticola than on Akodon azarae. Androlaelaps rotundus was dominant and exhibited higher values of mean abundance and prevalence on A. azarae, Mysolaelaps microspinosus on $\mathrm{O}$. flavescens and Gigantolaelaps mattogrossensis on O. delticola.
\end{abstract}

Key words: mites - Laelapidae - sigmodontine - Argentina

Laelapidae is one of the most important families of the Acari Subclass in number of species (Strandtmann \& Wharton 1958) and most of them are ectoparasites of vertebrates. In Argentina, most of the studies reported are on species associated with rodents in the province of Buenos Aires only. Relatively few ecological studies were made and the most relevant were obtained from the following localities: General Pueyrredon (Fernandez 1977), Punta Lara (Lareschi 1996) and Berisso (Liljesthröm $\&$ Lareschi 2001). Here, the richness, diversity, abundance and prevalence of mite species associated with sigmodontine rodents of different species were studied in Entre Ríos province, Argentina.

The mites were collected on rodents captured alive from 20 to 27 July of 1998. In total, 48 individuals were examined: Akodon azarae (27), Oligoryzomys flavescens (11) and O. delticola (10). The specimens are housed at the Mammalogy Collection of the Department of Vertebrate Zoology, La Plata Museum, Argentina. The ectoparasites were recovered by hand from the host's coat. They were preserved in $70 \%$ ethanol and subsequently mounted on permanent slides for taxonomic identification. Representative specimens have been

\footnotetext{
Supported partially by the municipality of Villa Elisa, Entre Ríos, Argentina.

${ }^{+}$Corresponding author. E-mail: amabba@lycos.com and ferpao@netverk.com.ar

Received 8 March 2001

Accepted 31 July 2001
}

housed over to the Collection of the Department of Entomology, La Plata Museum. The identification of the mites is according to Furman (1972). For each host species the richness ( $\mathrm{S}=$ number of species), Shannon diversity species index $\left(\mathrm{H}=-\sum\right.$ [pi $\left.\left.\ln \mathrm{pi}\right]\right)$, mean abundance (MA = total number of individuals of a particular parasite species - or taxonomic group - in a sample of a particular host species divided by the total number of hosts of that species, including both infected and non-infected hosts) and prevalence $[\mathrm{P}=$ (number of hosts infected with one or more individuals of a particular parasite species - or taxonomic group - divided by the number of hosts examined for that parasite species) $x$ 100] were calculated.

The study area comprises the first $5 \mathrm{~km}$ of the Perucho Verna stream located in Villa Elisa (Entre Ríos, 32 $2^{\circ} 10^{\prime}$ 'S, $\left.58^{\circ} 24^{\prime} \mathrm{W}\right)$. In total, 466 mites representing the following six species were collected from the 48 rodents: Order Parasitiformes, Family Laelapidae: Androlaelaps fahrenholzi (Berlese), Androlaelaps rotundus (Fonseca), Gigantolaelaps mattogrossensis (Fonseca), Laelaps manguinhosi Fonseca, Laelaps paulistanensis Fonseca, and Mysolaelaps microspinosus Fonseca. The number of mites collected and the values of mean abundance, prevalence, diversity index and richness on each rodent species are shown in Table I. The number of specimens of each mite species as well as the abundance, mean abundance and prevalence on every host species are shown in Table II.

Although the six species of mites have been previously recorded in Argentina (Lareschi \& Mauri 1998), except L. manguinhosi (Lareschi et al. un- 
TABLE I

Richness (S), diversity index $(\mathrm{H})$, mean abundance (MA) and prevalence (P; \%) on each host species

\begin{tabular}{lccccc}
\hline Hosts & \multicolumn{5}{c}{ Mites } \\
\cline { 2 - 6 } Species (no. collected) & Total & M A & P \% & H & $\mathrm{S}$ \\
\hline Akodon azarae (27) & 290 & 10.7 & 92.6 & 0.58 & 4 \\
Oligoryzomys flavescens (11) & 116 & 10.5 & 100 & 1.2 & 5 \\
Oligoryzomys delticola (10) & 60 & 6 & 90 & 1.5 & 5 \\
\hline Total (48) & 466 & 9.7 & 93.7 & 1.5 & 7 \\
\hline
\end{tabular}

TABLE II

Number of specimens (No. ), abundance (A\%), mean abundance (MA) and prevalence (P; \%) of each mites species on every rodent species

\begin{tabular}{|c|c|c|c|c|c|c|c|c|c|c|c|c|}
\hline \multirow[b]{3}{*}{ Mites } & \multicolumn{12}{|c|}{ Hosts } \\
\hline & \multicolumn{4}{|c|}{ Akodon azarae } & \multicolumn{4}{|c|}{ Oligoryzomys flavescens } & \multicolumn{4}{|c|}{ Oligoryzomys delticola } \\
\hline & No. & $\mathrm{A}(\%)$ & MA & $\mathrm{P}(\%)$ & No. & $\mathrm{A}(\%)$ & MA & $\mathrm{P}(\%)$ & No. & $\mathrm{A}(\%)$ & MA & $\mathrm{P}(\%)$ \\
\hline And & 60 & 20.6 & 2.3 & 33.3 & 2 & 1.7 & 0.18 & 18.2 & 7 & 11.6 & 0.7 & 30 \\
\hline Andro & 226 & 78 & 8.4 & 95.6 & - & - & - & - & - & - & - & - \\
\hline Gigantolaelaps mattogrossensis & - & - & - & - & 21 & 18.1 & 1.9 & 72.7 & 20 & 33.3 & 2 & 70 \\
\hline Laela & - & - & - & - & 23 & 19.8 & 2.1 & 45.4 & 12 & 20 & 1.2 & 60 \\
\hline Laela & - & . & - & - & 7 & 6 & 0.6 & 27.3 & 14 & 23.5 & 1.4 & 50 \\
\hline Mysolaelaps microspinosus & 2 & 0.7 & 0.1 & 3.7 & 63 & 54.4 & 5.7 & 81.8 & 7 & 11.6 & 0.7 & 20 \\
\hline
\end{tabular}

published observation), the other five species are reported for the first time in the province of Entre Ríos. A. rotundus is specific on A. azarae. On the other hand, A. fahrenholzi and M. microspinosus are associated with all the host species. $G$. mattogrossensis, L. manguinhosi and L. paulistanensis are specific at the host-genus level. Comparing mean abundance and prevalence, the sequence of hosts for $M$. microspinosus is $O$. flavescens, $O$. delticola and A. azarae.

Since many rodents are reservoirs of diseases, those species collected on different host species may play an important role in epizootics and in the perpetuation of diseases among them, as tularemia, relapsing fever and rickettsial infections (Tipton 1960). On the other hand, the dominance of each mite species on different host species, obtained in this study, are in line with similar studies carried out in localities of the province of Buenos Aires (Fernandez 1977, Lareschi 1996, Liljesthröm \& Lareschi 2001). Acording to Kim (1985), who supports that in an ectoparasitic community the dominant species on a host species are usually well defined and consistent throughout with the range of its host distribution, these results are important because, allied with other sort of studies, constitute an important step for correct identification of the host.

\section{ACKNOWLEDGMENTS}

To WO Udrizar Sauthier, R Imoberdoff and PM Simón for their valuable assistance in the field work, to PM Linardi (UFMG, Brasil) for his critical lecture of the manuscript, to IF de Cassé, Ernesto Lofeudo and SF Vizcaíno (FCNyM, Argentina) for the critical revision of the English and UFJ Pardiñas (FCNyM, Argentina) for the systematic revision of the rodents.

\section{REFERENCES}

Fernandez NA 1977. Acaros parásitos de roedores del sector costero del partido de Gral. Pueyrredon (Bs. As., Argentina). Com Mus Munic Cs Nat.’Lorenzo Scaglia", p.1-8.

Furman DP 1972. Laelapid mites (Laelapidae: Laelapinae) of Venezuela. Brigham Young Univ Sc Bull 17: 58 pp.

Kim KC 1985. Coevolution of Parasitic Arthropods and Mammals, London University Press, London, 745 pp.

Lareschi M 1996. Estudio preliminar de la comunidad de roedores (Rodentia: Muridae) y sus ectoparásitos (Acari, Phthiraptera y Siphonaptera) en Punta Lara (Buenos Aires). Rev Soc Entomol Argen 55: 113-120.

Lareschi M, Mauri R 1998. Dermanyssoidea. In JJ Morrone, S Coscarón (eds), Biodiversidad de Artrópodos Argentinos. Una Perspectiva Biotaxonómica, Ediciones Sur, La Plata, p. 581-590.

Liljeström G, Lareschi M 2001. Estudio preliminar de la comunidad ectoparasitaria de roedores sigmodontinos en el partido de Berisso, provincia de Bs. As. Actualizaciones en entomo-epidemiología Argentina, CeNDIE, Ministerio de Salud y Acción Social de la Nación, Argentina.

Strandtmann RW, Wharton GW 1958. Manual of Mesostigmatid Mites, Contribution no. 4 of The Institute of The Acarology, CE Yunker, $330 \mathrm{pp}$.

Tipton VJ 1960. The genus Laelaps. Univ of California Press 16: 233-356. 